\title{
Influence of the use of manioc on its genetic diversity conservation in a quilombo community in Mato Grosso, Brazil
}

\author{
J.R.L. Oler ${ }^{1}$, E.S.S. Hoogerheide ${ }^{2}$, J.M.A. Pinto ${ }^{2}$, A.V. Tiago ${ }^{3}$, \\ J.F.V. Silva ${ }^{4}$ and E.A. Veasey ${ }^{5}$ \\ ${ }^{1}$ Universidade Estadual Paulista "Júlio de Mesquita Filho", Campus Rio \\ Claro, Instituto de Biociências, Departamento de Botânica, Rio Claro, SP, \\ Brasil \\ ${ }^{2}$ Embrapa Agrossilvipastoril, Sinop, MG, Brasil \\ ${ }^{3}$ Programa de Pós-graduação Biodiversidade e Biotecnologia da Amazônia \\ Legal, PPG-Bionorte, Laboratório de Genética Vegetal e Biologia \\ Molecular, Universidade do Estado de Mato Grosso, Campus de Alta \\ Floresta, MG, Brasil \\ ${ }^{4}$ Embrapa Sede, Brasília, DF, Brasil \\ ${ }^{5}$ Departamento de Genética, Escola Superior de Agronomia "Luiz de \\ Queiroz”, Universidade de São Paulo, Piracicaba, SP, Brasil \\ Corresponding author: E.S.S. Hoogerheide \\ E-mail: eulalia.hoogerheide@embrapa.br
}

Genet. Mol. Res. 18 (3): gmr18326

Received April 17, 2019

Accepted July 11, 2019

Published July 30, 2019

DOI http://dx.doi.org/10.4238/gmr18326

\begin{abstract}
Local cassava varieties play an important role in food security and the autonomy of subsistence farmers. They can be important resources for breeding and conservation programs. We examined the genetic diversity of cassava through ethnobotanical knowledge and microsatellite markers to understand the dynamics of conservation and management of the varieties used local small-scale farmers of a rural quilombo (a slave-descendant community) in Mato Grosso, Brazil. To obtain ethnobotanical information, semi-structured interviews were applied to 10 family units who cultivated cassava. Each family cultivated from one to five varieties, with $2.3 \pm 1.16$ varieties/farmer, on average. Genetic analysis was was made of the 11 local varieties with microsatellite markers (12 loci). Despite low ethnobotanical diversity ( $\mathrm{H}^{\prime}$ $=2.05)$, high genetic diversity was found $(\mathrm{Na}=6.75, \mathrm{HO}=0.92, \mathrm{HE}=$ 0.75 , on average) in these local varieties. These farmers, who derive their
\end{abstract}


income mainly from cassava cultivation and flour production for the market, direct their variety choices to those that are most productive. Brava variety was the most frequent (found in eight family units) and was considered the most profitable for the production of flour Network analysis showed that propagule circulation and information occurs between the residents and also with other communities of the region, which are important sources of new varieties. Two farmers were identified as the most active in this network, showing potential as key elements for the circulation of propagating material. According to the cluster analysis using the genetic data, the most recently introduced varieties (Baixinha, Liberatona, Broto roxo, Mansa, Ramo branco, Carneiro and Cuiabana) are separated from those introduced a long time ago. The varieties pointed out as bitter by the farmers were also grouped together. The results showed the importance of traditional farmers in maintaining a high genetic diversity of manioc varieties, despite the directing of the choice of varieties to meet market needs.

Key words: Agrobiodiversity; Ethnobotany; Quilombo; On farm conservation

\section{INTRODUCTION}

Traditional farmers are pointed out by many researchers as the principal maintainers of agrobiodiversity, including those who produce cassava (Amorozo, 2013). In general, traditional farmers have ties of kinship, and a high degree of knowledge, passed on from generation to generation, of the environment in which they live. Plants managed in traditional agriculture are essential to the continuity of communities, as they provide the food base of the group. Traditional agriculture is usually subsistence oriented, using local inputs and simple technology.

Manioc (Manihot esculenta) is an important food crop, especially for traditional tropical populations. Responsible for the supply of carbohydrates to approximately 600 million people, it occupies the third position among the most important crops for the world population (Olsen and Schaal, 1999). Considered a key species, cassava plays an important role in food security and the autonomy of subsistence farmers with little capacity to acquire external inputs, due to a number of advantages over other crops such as drought tolerance, easy propagation, satisfactory yield even in relatively unfertile soils and high intraspecific diversity (Peroni and Hanazaki, 2002).

Many studies highlight the considerable diversity of local varieties of cassava cultivated by traditional farmers in different Brazilian locations (Emperaire and Peroni, 2007; Amorozo, 2010; Marchetti et al., 2013), and the high genetic diversity managed in traditional communities (Salick et al., 1997; Siqueira et al., 2010; Alves-Pereira et al., 2011). Such diversity can be attributed to the possible origin and domestication of the plant in a region that extends from the Amazon to Mato Grosso (Olsen and Schaal, 1999). The studies of Olsen and Shaal (1999) were validated by Léotard et al. (2009), which suggested that domestication occurred in the are comprised by the northern states of Mato Grosso, Rondônia, Acre, and in the border with Bolivia.

The region known as Baixada Cuiabana is located north of the Mato Grosso Pantanal (an immense swamp region), being one of the few regions in Mato Grosso that still 
preserves the old characteristics of subsistence farmers' communities. It occupies a secular area of sesmarias, which are abandoned lands distributed to the new settlers by the Portuguese Crown. In the Baixada Cuiabana, such areas have as a characteristic food production directed to the subsistence of families; there is communal use of the lands and division of agricultural activities among relatives (Castro, 2009). This region is populated by traditional communities of small farmers who maintain a significant diversity of cassava and other crops (Amorozo, 2010). These communities include quilombos (escaped slavedescendant communities).

São Benedito community, the object of this research is located in Poconé. Poconé is one of the municipalities that integrates the Baixada Cuiabana region. It is made up of traditional quilombo farmers who live from cassava cultivation and artisanal flour production, with $91 \%$ of the families having this activity as their main income source (Duarte, 2015).

For this group of farmers, cultivated local varieties of cassava have an intrinsic historical-cultural value, since this crop is directly related to the survival of the families. Duarte and Pasa (2016) emphasized the importance of cassava cultivation, including the production of flour for the community and the managed agrobiodiversity. In this context, a major challenge is to reconcile the conservation of genetic resources, increase productivity and achieve ecological management of the system, i.e., how to develop and improve agricultural ecosystem productivity to alleviate poverty and ensure food security in a sustainable way.

Consequently, ethnobotanical tools and molecular techniques were applied in this study to understand the relationships of the farmers with the cassava collection managed and preserved by them. Ethnobotanical studies provide important information on species biology/ecology, appropriate management techniques, among others, facilitating the implementation of different actions aimed at the conservation of agrobiodiversity and/or plant breeding (Ford, 2000). Microsatellites or simple sequence repeat (SSR) markers have been widely used to analyze the genetic diversity of manioc (Siqueira et al., 2010; AlvesPereira et al., 2011). However, there are only a few studies carried out in the state of Mato Grosso, and even more scarce are studies that link genetic analyses to ethnobotanical knowledge (Carrasco et al., 2016). Kombo et al. (2012) emphasize that for a better understanding of the managed diversity, different aspects must be analyzed so that the result is not under or overestimated.

Considering the panorama presented, this study aimed to characterize the genetic diversity of cassava through ethnobotanical/traditional knowledge and microsatellite markers to understand the dynamics of conservation and management of the collection of varieites used by the farmers of São Benedito Community, Poconé, Mato Grosso.

\section{MATERIAL AND METHODS}

\section{Study area}

The study was carried out in São Benedito Community, in the municipality of Poconé, Mato Grosso, Brazil, located 100 kilometers from the state capital, Cuiabá (Figure 1). Belonging to the area called Baixada Cuiabana, Poconé has a population of 31,779 
inhabitants, with a demographic density of less than two inhabitants per square kilometer. The economy is mainly based on the services sector, followed by agriculture (IBGE, 2017).

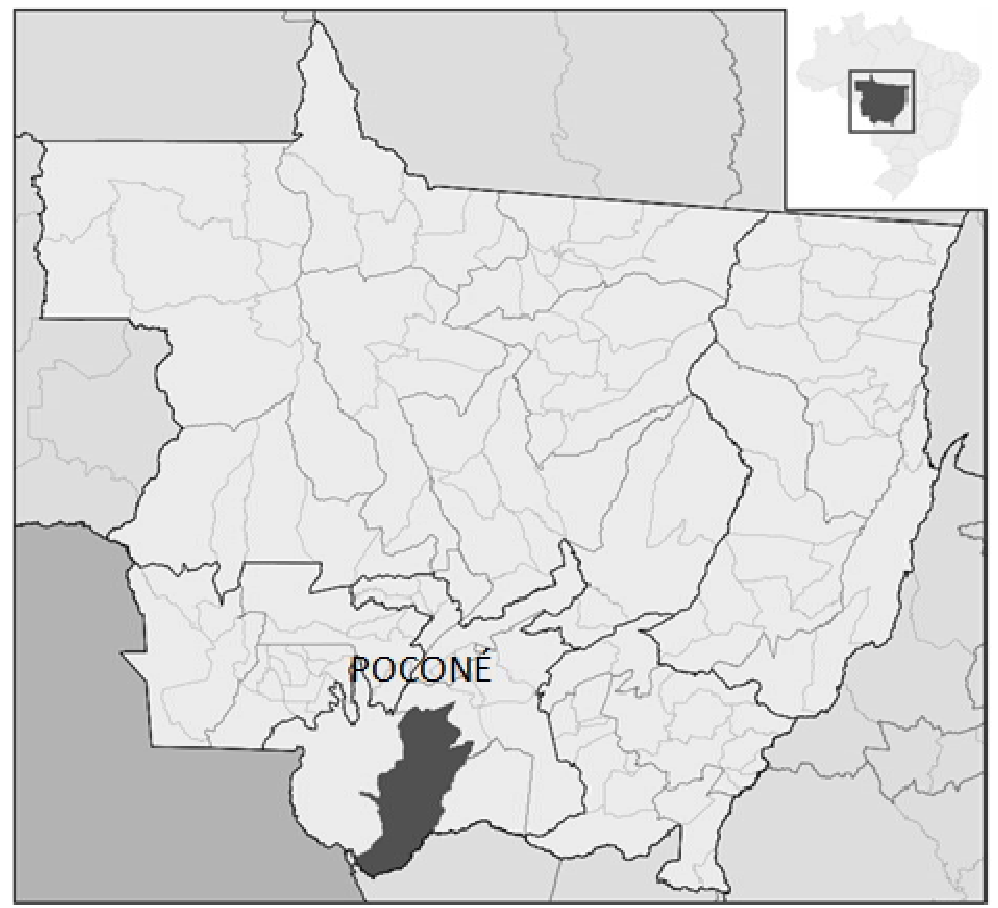

Figure 1. Map of the municipality of Poconé, Mato Grosso, Brazil. Source: https://commons. wikimedia.org/w/index.php?curid=1417344

Based on the Köppen classification, the climate of the region is tropical, with two well defined seasons. The maximum precipitation occurs between December and February and the annual average is $1500 \mathrm{~mm}$. With a large thermal amplitude, the maximum temperature is $42^{\circ} \mathrm{C}$ and the minimum is $4{ }^{\circ} \mathrm{C}$, with the annual average being $24^{\circ} \mathrm{C}$. The region presents areas with flora and fauna typical of Cerrado and a transition to Pantanal (Duarte and Pasa, 2016; IBGE, 2017).

The São Benedito community (1600'54.6' S; 56 59'11.2'” W) was established in the 50's and was recognized as a remnant of a quilombo in 2010. It is currently in the third generation that maintains agricultural activity. There are 81 residents living in this community distributed in 23 family units. Family income is basically from subsistence farming and cassava flour production (Duarte, 2015). The size of farmers' fields varies between 0.5 and 2.5 hectares. There is a common area where they all produce the flour together, but each farmer has his own cassava crop and, therefore, his own varieties collection (Duarte, 2015).

\section{Field data collection}

The research was carried out from September to December 2015. Semi-structured ethnobotanical interviews were applied to 10 farmers (AGRA, AGRB, AGRC, AGRD, 
AGRE, AGRF, AGRG, AGRH, AGRI, AGRJ) who cultivate cassava, on processes of choice, substitution and abandonment of varieties (why do you grow or do not grow a specific variety), nomenclature (origin and reason for the nomenclature), management (time to produce, variety resistance), characterization (color of the skin, cortex and pulp, toxicity) and dissemination of propagules through the social network (from whom you have received and to whom you donated material from each variety cultivated in the 2015/2016 harvest). For the item toxicity, which separates the varieties into bitter and sweet, the classification was based on a folk classification, and no biochemical analyses were performed.

The participant observation technique was used to better understand socio-cultural and economic influences on agricultural activity (Viertler, 2002). It is worth noting that by local variety we mean the set of clones grouped by farmers as a single variety due to the phenotypic similarities they present (Elias et al., 2004). This work was authorized by the Conselho de Gestão do Patrimônio Genético (CGEN-MMA, Process No. 02000.003025 / 2013-13 - MMA deliberated on April 28, 2015 and published in the O.D.U. of July 13, 2015), and was registered at SisGen under the registration number A3DF14E.

\section{Molecular characterization}

To assess the genetic diversity, microsatellite markers (SSR) were used. Farmer fields were visited and two newly expanded leaves of each local variety (11) were collected and transported in $1.5 \mathrm{~mL}$ polypropylene microtubes containing $1 \mathrm{~mL}$ of saturated $\mathrm{NaCl}-$ CTAB solution (6 M NaCl, $40 \mathrm{mM} \mathrm{CTAB})$. Samples were maintained for seven days at $4^{\circ} \mathrm{C}$, aiming at the best performance of the gel to stabilize the material. After this period, the leaves were sanitized and macerated in a solution of $1.5 \mathrm{~mL}$ STE buffer $(250 \mathrm{mM}$ sucrose, 3 $\mathrm{mM}$ Tris $\mathrm{HCl}, 5 \mathrm{mM}$ EDTA). DNA of the 11 samples were extracted according to the methodology proposed by Doyle and Doyle (1990), with the changes described by Siqueira et al. (2009). DNA quality and concentration were obtained using $0.8 \%$ agarose gel electrophoresis and spectrophotometer NanoDrop 2000, respectively.

Twelve microsatellite loci were chosen based on Chavarriaga-Aguirre et al. (1998) (GAGG-5, GA-12, GA-21, GA-131, GA-136, GA-140) and Mba et al. (2001) (SSRY-8, SSRY-21, SSRY-28, SSRY-35, SSRY-40, SSRY-43).

Amplifications were performed following the protocol of Schuelke (2000) with the addition of an M13 tail at the 5' end in the forward primer, and the chosen fluorescence was coupled to that primer (HEX or FAM). Reactions contained 10-50 ng of genomic DNA, 0.6 or $0.7 \mathrm{mM} \mathrm{MgCl}_{2}, 1 \mathrm{x}$ buffer, $0.2 \mathrm{mM}$ of each dNTP, $0.25 \mu \mathrm{L}$ forward primer and $0.5 \mu \mathrm{L}$ for the reverse primer, 0.25 pmol universal M13 and $1.25 \mathrm{U}$ Taq DNA polymerase (Invitrogen, Carlsbad, California). The amplification program consisted of a denaturation at $94^{\circ} \mathrm{C}$ for 5 minutes, followed by 30 cycles of $30 \mathrm{~s}$ at $94^{\circ} \mathrm{C}, 45 \mathrm{~s}$ varying from $45^{\circ} \mathrm{C}$ to $56^{\circ} \mathrm{C}, 45 \mathrm{~s}$ at $72^{\circ} \mathrm{C}$ and 8 cycles of $30 \mathrm{~s}$ at $94^{\circ} \mathrm{C}, 45 \mathrm{~s}$ at $53^{\circ} \mathrm{C}, 45 \mathrm{~s}$ at $72^{\circ} \mathrm{C}$. The reactions were sent to São Paulo and genotyped in an ABI3730 automatic sequencer in the DNA Sequencing Sector of the Human Genome and Stem Cell Research Center of the Biosciences Institute of the University of São Paulo. The reading in the automatic sequencer generated files containing the electropherogram peaks, which were analyzed using the GeneMarker ${ }^{\circledR}$ v. 1.95 (Softgenetics). 


\section{Statistical analysis}

The ethnobotanical knowledge analyses were performed using descriptive statistics and qualitative techniques (Huberman and Miles, 1994), calculating the wealth ( $S=$ number of local cultivated varieties) and the Shannon-Wiener $\left(H^{\prime}\right)$ diversity index adapted for ethnobotany (Begossi, 1996). We decided to use base 10 and base $e$, to facilitate comparison with other studies. For these analyses, the PAST program version 2.17c (2013) was used (Hammer et al., 2001).

The cluster analysis was constructed using the UPGMA (Unweighted pair group method of arithmetic averages) method and the Sørensen coefficient of similarity obtained from a matrix of presence and absence of the citation of each local variety of manioc by the interviewee, due to the binary nature of the data, failure to consider double-absences and to give weight to what is actually present in the sample. Analyses and graphs were generated using the program R Development Core Team (2016). The graphical representation of the circulation networks was built with the help of the Pajek (Program for Large Network Analysis) program (Batagelj and Mrvar, 1998) using the Kamada-Kawai Layout.

To analyze the genetic diversity, the following indices were estimated: average number of alleles per locus $(\bar{A})$, percentage of polymorphic loci $(P \%)$, allele frequencies, observed heterozygosity $\left(H_{O}\right)$ and expected $\left(H_{E}\right)$, and Wright's fixation index $(F)$. The organization of genetic diversity was also evaluated through the analysis of principal coordinates (PCoA) at the individual level through the GenAlEx 6.5 program (Peakall and Smouse, 2006). The polymorphism information content (PIC) and the multivariate analysis (cluster analysis) using the UPGMA method and Nei's genetic distance (Nei, 1972) were obtained using the Power Marker program (Liu and Muse, 2005).

\section{RESULTS}

Each family unit cultivated from 1 to 5 varieties, with $2.3 \pm 1.16$ varieties/farmer, on average. Farmers in São Benedito community divide manioc into bitter and sweet varieties. This division is quite common among communities cultivating manioc (ChiwonaKarltin et al., 2004; Marchetti et al., 2013; Carrasco et al., 2016). This separation is based on the cyanogenic potential of the roots. Sweet varieties have low amounts of cyanogenic glycosides and can be consumed with simple processing (cooking or sometimes even raw). On the other hand, bitter varieties have large amounts of glycosides and require detoxification and processing before consumption (McKey and Beckerman, 1993; Clement et al., 2010). The main attribute used to identify a bitter variety in the community is the bitter taste. Studies by Amorozo (1996) and Marchetti et al. (2013) in traditional communities of Baixada Cuiabana, also highly dependent on the production of flour, found local bitter varieties being cultivated. The farmers used an evaluation system for identification based mainly on the bitter taste of the roots. The same system was also found among Malawi farmers in southern Africa (Chiwona-Karltin et al., 2004), where the authors found a positive and significant correlation between bitter taste and high concentration of cyanogenic glycosides. Because they present higher yields for the production of flour and manioc starch, bitter manioc are generally the most frequent among communities highly dependent on the production of these manioc by-products (Amorozo, 1996). They are 
chosen mainly because they present a drier mass, which facilitates in the manufacture, mainly artisanal (Marchetti et al., 2013).

The farmers mentioned that they use the bitter and sweet criterion to produce separate manioc fields, taking care to avoid intoxication. The distance between varieties will prevent spontaneous natural crosses between them. The amplification of genetic diversity in manioc occurs because, despite being vegetatively propagated by farmers, its sexual reproduction system remains active, presenting pollination and fruit dehiscence, and therefore, new varieties can be generated through sexual reproduction (Martins and Oliveira, 2009).

Another attribute mentioned by the farmers was the color of the pulp (Table 1). We noticed that all local varieties in the study area present a white color pulp. In the State of Mato Grosso, the preference for flour coloring can vary between white and yellow, of the dry type, with fine to coarse granulation. In regions that prefer yellow flours, the varieties with this pulp color are selected, as is the case in the northern region of the country (Cereda and Vilpoux, 2010).

The characteristic time to produce, which is the time at which manioc can be harvested, is an important agronomic characteristic, as it influences the organization and scheduling of the swidden fields. As observed in Table 1, the variety denominated Brava (bitter), cultivated by eight farmers, has the shortest cycle, from six to eight months. Another attribute that influences seasonality is what they call resistance in the soil, which is the cycle of the material. It is again noted that the Brava variety is the longest remaining in the soil, up to 36 months. Such a characteristic may be promising for soil diseases resistance genes. Bandyopadhyay et al. (2006) mention that there is a great diversity of species that cause manioc root rot, and it is not possible to say which is the most important. It is worth mentioning that the São Benedito community produces flour throughout the year to serve the market of the city of Poconé, as well as making extra sales to the capital, Cuiabá. To meet the consumer market and maintain the frequency of production, the raw material is required. Thus, both associated characteristics, precocity and long-term soil maintenance, make the Brava variety the most cited by farmers, being present in $80 \%$ of the fields visited (8 family units), as shown in Figure 2.

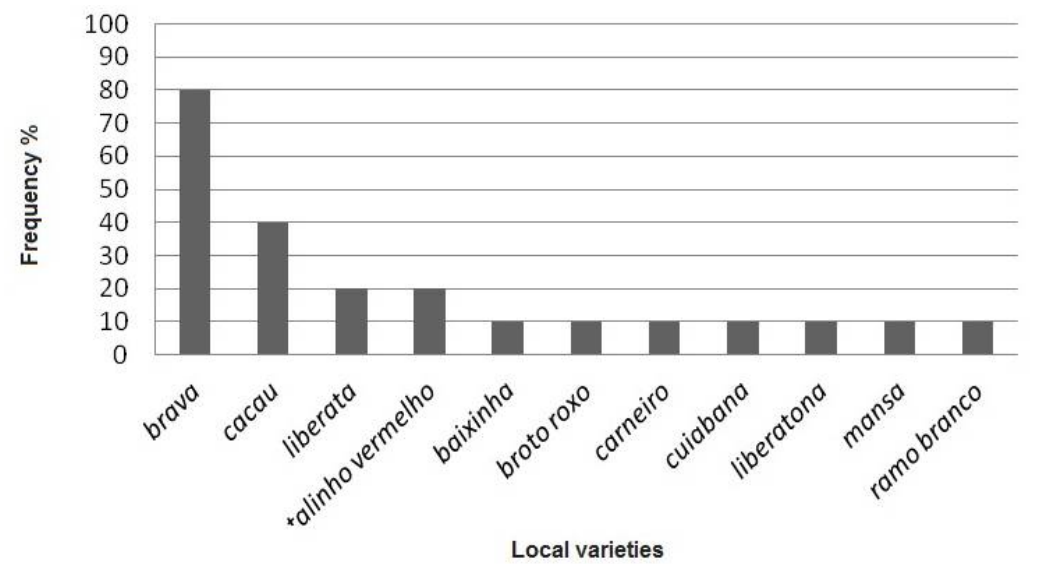

Figure 2. Frequency of local varieties of manioc cultivated by farmers in São Benedito Community, Poconé, Mato Grosso. 
Table 1. Ethnobotanic characterization of 11 local varieties of manioc cultivated in São Benedito Community, Poconé, Mato Grosso.

\begin{tabular}{|c|c|c|c|c|c|c|c|c|}
\hline \multirow[b]{2}{*}{$\begin{array}{l}\text { Local } \\
\text { varieties }\end{array}$} & \multicolumn{7}{|c|}{ Ethnobotanical characterization } & \multirow[b]{2}{*}{ Farmers } \\
\hline & Toxicity $^{1}$ & Uses $^{2}$ & Skin & Cortex & Pulp & $\begin{array}{l}\text { Time to } \\
\text { produce } \\
\text { (months) }\end{array}$ & $\begin{array}{l}\text { Soil resistance } \\
\text { (months) }\end{array}$ & \\
\hline Baixinha & Sweet & $\mathrm{C}$ & Brown & White & White & 12 & 24 & AGRD \\
\hline & & & & & & & & $\begin{array}{l}\text { AGRA, } \\
\text { AGRB, } \\
\text { AGRC, }\end{array}$ \\
\hline Brava & Bitter & $\mathrm{F}$ & Brown & Red & White & 6 to 8 & 24 to 36 & $\begin{array}{l}\text { AGRD, } \\
\text { AGRE, } \\
\text { AGRF, } \\
\text { AGRG, } \\
\text { AGRI }\end{array}$ \\
\hline Broto Roxo & Sweet & $\mathrm{C} ; \mathrm{F}$ & Brown & Purple & White & 8 & 24 & AGRD \\
\hline Cacau & Sweet & $\mathrm{C}$ & Brown & Red & White & 6 to 10 & 12 to 24 & $\begin{array}{l}\text { AGRE, } \\
\text { AGRG, } \\
\text { AGRH, } \\
\text { AGRJ }\end{array}$ \\
\hline Carneiro & Sweet & $\mathrm{C} ; \mathrm{F}$ & Brown & Pink & White & 12 & No information & AGRH \\
\hline Cuiabana & Sweet & $\mathrm{C}$ & Brown & Red & White & 8 & 24 & AGRB \\
\hline Liberata & Sweet & $\mathrm{C} ; \mathrm{F} ; \mathrm{S}$ & Brown & White & White & 12 & 24 & $\begin{array}{l}\text { AGRD, } \\
\text { AGRE }\end{array}$ \\
\hline Liberatona & Sweet & $\mathrm{C} ; \mathrm{F}$ & Brown & Purple & White & 8 & 24 & AGRD \\
\hline Mansa & Sweet & C; F; S & Brown & Purple & White & 12 & 24 & AGRF \\
\hline Ramo Branco & Sweet & $\mathrm{F}$ & Brown & White & White & 8 & 24 & AGRJ \\
\hline Talinho Vermelho & Bitter & $\mathrm{F}$ & Brown & Yellow & White & 8 to 12 & 24 & $\begin{array}{l}\text { AGRC, } \\
\text { AGRH }\end{array}$ \\
\hline
\end{tabular}

${ }^{1}$ Farmer's classification; ${ }^{2} \mathrm{C}$ - consumption; $\mathrm{F}$ - flour production; $\mathrm{S}$ - sales

It is important to emphasize that since communities are always exposed to changes, whether socioeconomic or environmental, these choices may change over time, which shows the adaptability of traditional agriculture. The most appropriate local varieties to the current reality will always be the ones recruited (Hamlin and Salick, 2003). However, it is noted that the Brava variety currently has a great contribution to make the economic activities feasible for these farmers. The pattern found in the São Benedito community is similar to those found in other traditional communities. According to Amorozo (2010), it is common for a more frequent variety to be seen in many family units and for several varieties to be cultivated by only a few farmers. In general, in traditional households the cultivation of more than one variety per swidden field is common, as well as the entrance of material through the circulation network of propagation material, an important source of genetic variability and information (Thomas et al., 2011).

In the São Benedito community, we observed that although the Brava variety is the most planted, the farmers maintain others in their fields. Table 1 shows that three varieties have aptitude for household consumption (sweet varieties) and eight are destined for flour or double function, which indicates that the farmers prefer to conserve varieties with important characteristics for the flour production.

The intermediate frequency varieties were Cacao and Liberata, as well as Talinho vermelho (Figure 2). Such varieties were probably mentioned due to multiple uses (consumption, flour and sales). They also appear among the most frequent in other communities of the Baixada Cuiabana due to the good characteristics of adaptability and yield (Carrasco et al., 2016). 
A total of 81 alleles were found in the genetic analysis with microsatellite markers (Table 2), with a mean of $6.75 \pm 0.73$ alleles per locus, and $100 \%$ polymorphism. The number of alleles per locus varied between 4 (SSRY40) and 12 alleles (SSRY21). These values are above those found in other studies that analyzed the genetic diversity of manioc with the use of microsatellites, such as Siqueira et al. (2010) who studied plants of Mato Grosso do Sul, with an average of 6.0 alleles per locus for a total of nine loci, and Carrasco et al. (2016) who analyzed 211 accessions of local varieties of Mato Grosso with 14 loci and found an average of 3.6 alleles per locus. Therefore, the genetic diversity managed by farmers of São Benedito community is high.

Also, for all loci the fixation index $(F)$ was below zero, a fact that normally occurs when studying allogamous plants. All values were negative, which evidences the high heterozygosity. High values were found for $H_{O}(0.92)$ and $H_{E}(0.75)$ (Table 2). The values obtained also surpasses those found in studies on manioc genetic diversity throughout Brazil (Alves-Pereira et al., $2011-H_{O}=0.58, H_{E}=0.63$, for adult plants; Carrasco et al., 2016 $\left.H_{O}=0.6, H_{E}=0.58\right)$.

Table 2. Number of analyzed varieties $(\mathrm{N})$, average number of alleles per locus $(\mathrm{Na})$, observed heterozygosity $\left(H_{O}\right)$, expected heterozygosity or gene diversity $\left(H_{E}\right)$, fixation index $(F)$, content of polymorphic information (PIC) of local varieties of manioc analyzed in São Bernardo Community, Poconé, Mato Grosso.

\begin{tabular}{lccllll}
\hline Locus & $\mathbf{N}$ & $\boldsymbol{N a}$ & $\boldsymbol{H}_{\boldsymbol{O}}$ & $\boldsymbol{H}_{\boldsymbol{E}}$ & $\boldsymbol{F}$ & $\boldsymbol{P I C}$ \\
\hline SSRY21 & 11 & 12 & 0.91 & 0.87 & -0.04 & 0.86 \\
SSRY28 & 11 & 10 & 0.91 & 0.81 & -0.12 & 0.80 \\
SSRY35 & 11 & 6 & 0.91 & 0.71 & -0.28 & 0.66 \\
SSRY8 & 11 & 4 & 0.91 & 0.71 & -0.27 & 0.66 \\
GAGG5 & 11 & 3 & 0.55 & 0.42 & -0.31 & 0.36 \\
GA12 & 11 & 8 & 1.00 & 0.83 & -0.20 & 0.81 \\
GA21 & 11 & 6 & 1.00 & 0.75 & -0.34 & 0.71 \\
GA131 & 11 & 7 & 1.00 & 0.84 & -0.19 & 0.82 \\
SSRY43 & 11 & 7 & 0.91 & 0.80 & -0.14 & 0.77 \\
GA136 & 9 & 7 & 1.00 & 0.79 & -0.27 & 0.76 \\
GA140 & 9 & 7 & 1.00 & 0.79 & -0.27 & 0.76 \\
SSRY40 & 11 & 4 & 1.00 & 0.73 & -0.37 & 0.68 \\
Mean & 10.67 & 6.75 & 0.92 & 0.75 & -0.23 & 0.68 \\
\hline
\end{tabular}

This high diversity found in studies with cassava can be explained by the fact that it has been maintained by sexual reproduction for hundreds of years. And after domestication, the species is maintained through vegetative reproduction by farmers, constituting small genetic reservoirs of the species (Rogers and Fleming, 1973; Rival and McKey, 2008). This fact also contributed to the low value found for the fixation index, since in plants that usually cross, the individuals can suffer by inbreeding depression, often expressed in lesser or greater vigor. Thus, highly heterozygous cassava clones are selected and multiplied by farmers, avoiding sexual recombination and maintaining favorable genetic combinations of the variety (Rival and McKey, 2008).

The richness managed by the São Benedito community, meaning the total number of cultivated varieties ( $\mathrm{S}=11$ local varieties) is below that found in other studies in traditional Brazilian communities (Peroni and Hanazaki, 2002; $\mathrm{S}=62$; Amorozo, 2010; $\mathrm{S}=$ 60). Diversity index $\left(H^{\prime}\right)$ was 2.05 for calculations based on base $e$, and 1.31 for calculations 
with base 10. These values are also below those found by Marchetti et al. (2013) $\left(H^{\prime}=1.52\right)$ in their studies with traditional communities of the Baixada Cuiabana. This lower diversity managed by the farmers may be directly related to the need to cultivate more profitable local varieties for the production of flour, the main source of income for farmers. In these cases, the local varieties are chosen according to the need of the farmer, as discussed by Amorozo (2013).

Marchetti et al. (2013) found no significant difference between the diversity managed in 1992 and in $2011\left(H_{(1992)}^{\prime}=1.53 ; H_{(2011)}^{\prime}=1.52\right)$ when analyzing the temporal changes in diversity managed by communities of Santo Antonio do Leverger, in Mato Grosso State. However, when analyzing the number of varieties cultivated per farmer they found a marked decrease, from an average of $9.4 \pm 4.5$ in 1992 to $5.4 \pm 4.4$ in 2011, mainly due to the abandonment of agricultural activities by the younger ones, decrease in the cultivation areas and greater competition in the sales market of manioc flour.

In São Benedito community, the average number of varieties per farmer is $2.3 \pm 1.2$, which may be the result of the great interest and demand for more profitable varieties for flour production. The decrease in diversity is usually driven by factors that simplify the system (in this case specialization in varieties for flour production), resulting in the management of only a few varieties per crop, usually one (Peroni and Hanazaki, 2002).

Increasing crop homogeneity in more market-dependent communities is also discussed by Salick et al. (1997). Such a situation may represent a risk of loss of agrobiodiversity, and greater fragility of the agroecosystem, in the absence of new materials.

In order to understand the dynamics of circulation of the varieties cultivated by the farmers of São Benedito community, and to elucidate the findings mentioned above, a propagation material's exchange network was built (Figure 3) that connects the residents of the community. It is worth emphasizing that Emperaire and Peroni (2007) mention that this circulation is an important route of genetic variability, and an important source of renewal of germplasm, besides representing a source of knowledge on the cultivated material.

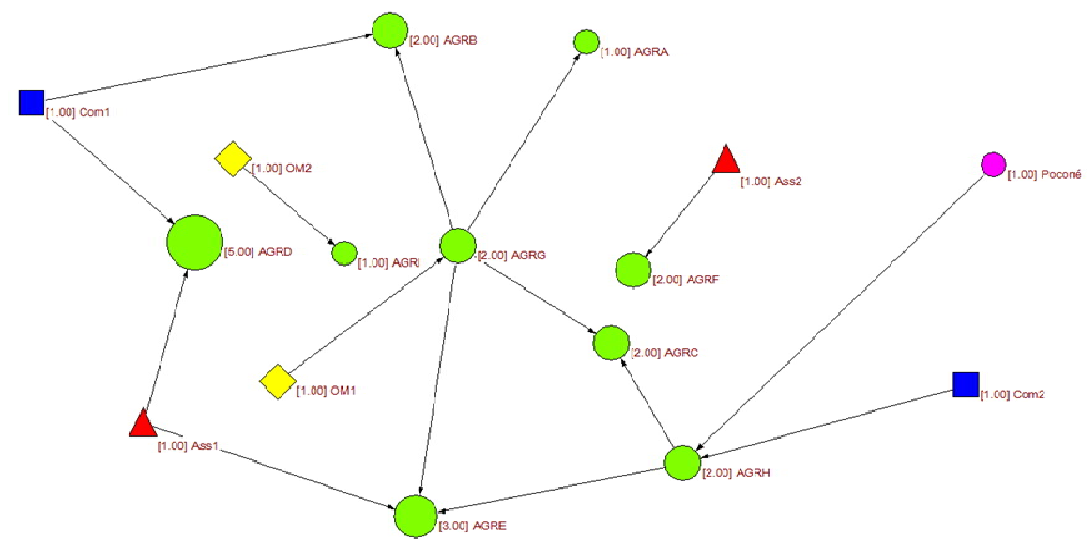

Figure 3. Graphical representation of the propagation material's exchange network of the São Benedito community. 2015/2016 crop production year. Layout: Kamada-Kawai. Green Circles - AGRA, AGRB, AGRC, AGRD, AGRE, AGRF, AGRG, AGRH, AGRI, AGRJ - Farmers; pink circle - City of Poconé; Squares - Com 1 and Com 2 Neighboring communities; Triangles - Ass1 and Ass2 - Nearby rural settlements; Diamonds - OM1 and OM2 - other non-studied community residents. The tip of the arrow indicates the place that received the local varieties. The size of the green circles represents the number of local varieties that the farmer cultivates (range 1-5). 
Two farmers stood out in the exchange network due to the greater number of interactions (five and four, respectively), namely: AGRG and AGRH (Figure 3). Both exchange materials (stems) with members of their own community, and with farmers from other communities, and are considered as key elements in the dynamics of propagule circulation during the study period (2015/2016). Identifying more farmers which are active in the propagule's circulation network within communities is important for participatory breeding programs or public policies for on-farm agrobiodiversity conservation (Montesano et al., 2012).

In the São Benedito community no interactions with other municipalities of the region were detected, which can be justified by the isolation of the studied community. However, the connection with neighboring communities may represent a link between the community and other regions. To better understand the dynamics of circulation, it is suggested that the communities mentioned be inserted in future studies.

The AGRD farmer stands out for being the one that manages most richness (five local varieties). However, he did not have a great active participation in the network. This situation may have occurred mainly because of the limitation of the method used that depends on the farmers' memory of the exchanges.

In the cluster analysis obtained from the citation of each local variety by interviewee, that is, when dealing with varieties maintained by the farmers, there were no formation of clusters, characterized by the cascade pattern presented (Figure 4).

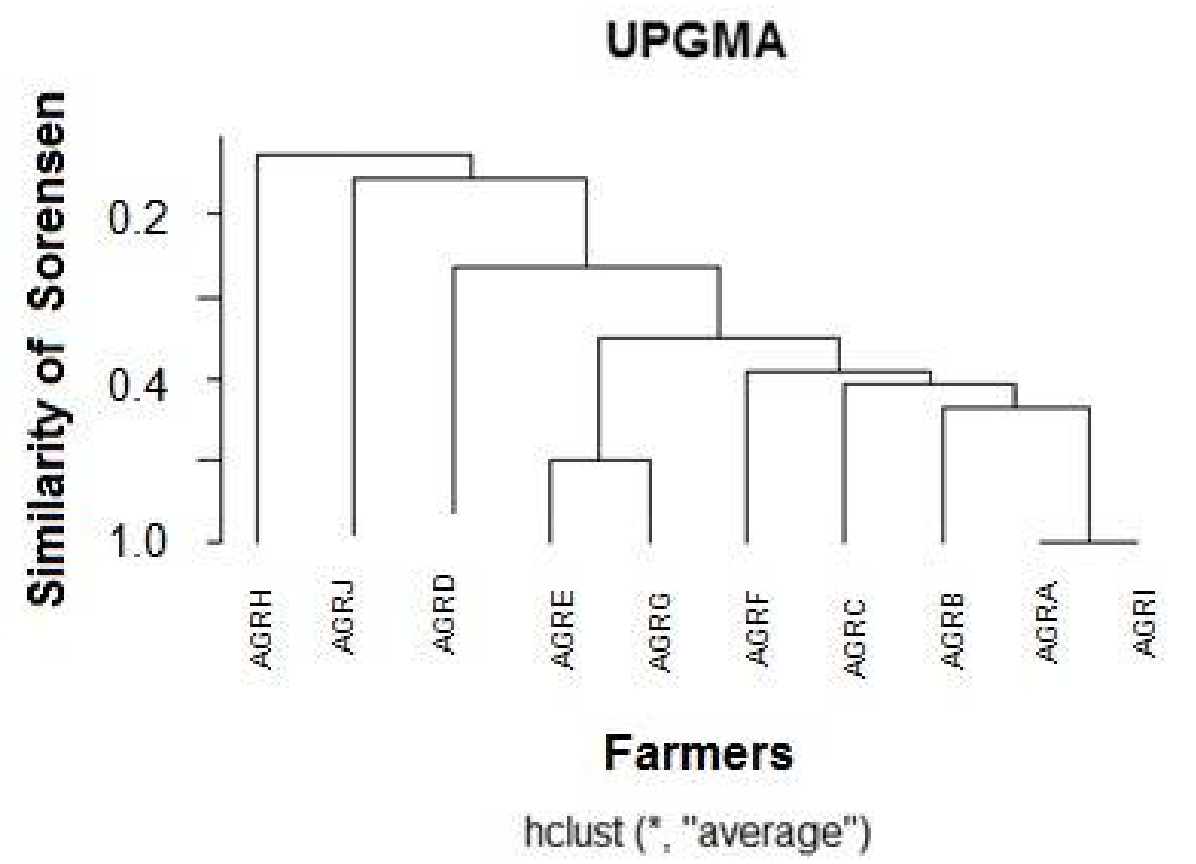

Figure 4. Cluster analysis for the citation of each local variety of manioc by the interviewee based on the Sørensen coefficient and method UPGMA (cophenetic correlation coefficient $=0.89$ ) for the São Benedito community. 
The maximum similarity was found between AGRA and AGRI farmers who only grow the local variety Brava. Also, AGRH, highlighted as an important element in the network of propagule's exchange, is the one that maintains the variety Carneiro, which reinforces its importance as a key element to handle rare varieties.

There are also situations in which a single farmer may be the main holder of diversity, being a key element, as discussed by Salick et al. (1997). Marchetti et al. (2013) found a farmer in the communities of Santo Antonio do Leverger who cultivated 24 varieties, corresponding to $64.9 \%$ of the varieties surveyed in 2011 , being also the main supplier of materials (stems) for the community. Such situations again demonstrate that policies for germplasm conservation, participatory breeding or on farm conservation agrobiodiversity, must detect and act together with the key elements, but also involve community actions, not only individual ones, in order to maximize results.

The cluster analysis using microsatellite markers classified the varieties into three groups (Figure 5). The first group classified the variety Baixinha (4), which was isolated and more genetically distant from the others. According to the farmer AGRD, who owns it, it comes from a Rural Settlement of the region and was introduced only five years ago. The second group was formed by the varieties Liberata (3), Brava (6), Cocoa (7) and Talinho vermelho (9), which have been cultivated for more than ten years in the community and are the most frequent varieties. The third included the varieties Liberatona (1), Broto roxo (2), Mansa (5), Ramo branco (8), Carneiro (10) e Cuiabana (11), introduced more recently and less frequent among farmers. Therefore, in this study we have observed that the most recently introduced varieties are separated from those introduced a long time ago.

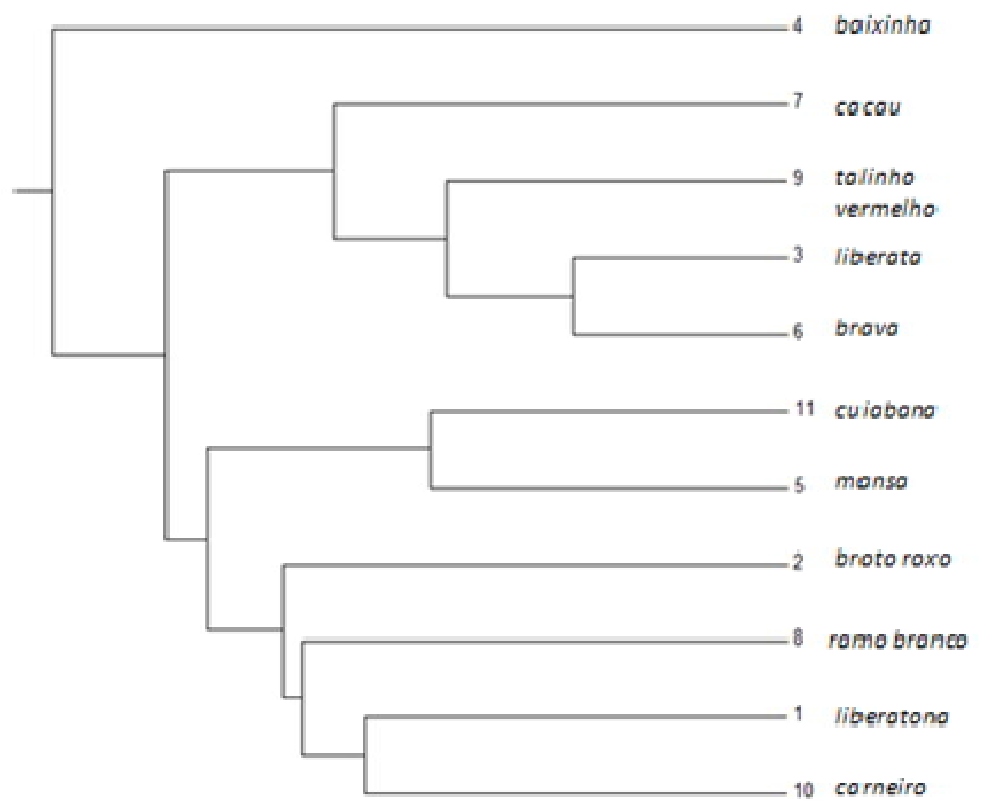

0000

Figure 5. Cluster analysis for the genetic analysis of manioc with 12 microsatellite loci, using the UPGMA method and Nei's genetic distance for 11 local varieties grown in the São Benedito community. 
In general, the results indicate high genetic diversity among the varieties. However, a low ethnobotanical diversity was found among the farmers when compared to other communities. In this sense, it is important to highlight that even with the high genetic diversity found, it is interesting that the farmers handle different local varieties so that they can guarantee the continuity of the process of maintenance and amplification of diversity. The low richness found in the swidden fields (number of varieties cultivated per farmer, 1 to 5 ) and in the community (total local varieties found, only 11) can be indicative of the need for actions that show the importance of conserving local varieties, even if only a few samples are kept, in their own home gardens, so that each family unit functions as a small germplasm reserve.

The Brava variety was the most planted due to its agronomic characteristics, and responsible for making flour production, the main income source of this community. According to farmers, this variety is the one with the highest flour production and that presents the least damage in the fields, because it is less susceptible to pests and diseases (Duarte, 2015). Studies of this nature demonstrate that the delimitation of areas for on-farm conservation of manioc should consider the populations that conserve and manage them, as well as the knowledge associated and maintained by traditional farmers.

\section{ACKNOWLEDGMENTS}

The authors are grateful to the residents of the São Benedito de Poconé Community who participated in the research. Molecular analyses were carried out at the Laboratory of Molecular Biology of Embrapa Agrossilvipastoril, Sinop, Mato Grosso. We also thank CAPES, CNPq, EMBRAPA and FAPEMAT development agencies, and the researcher Alessandro Alves-Pereira for the valuable contributions.

\section{CONFLICTS OF INTEREST}

The authors declare no conflict of interest.

\section{REFERENCES}

Alves-Pereira A, Peroni N, Abreu AG, Gribel R, et al. (2011). Genetic structure of traditional varieties of bitter manioc in three soils in Central Amazonia. Genetica. 139: 1259-1271.

Amorozo MCM (1996). Um sistema de agricultura camponesa em Santo Antônio do Leverger, Mato Grosso, Brasil. Doctoral Thesis, Faculdade de Filosofia Letras e Ciências Humanas, USP, São Paulo.

Amorozo MCM (2010). Diversidade agrícola em um cenário de transformação: será que vai ficar alguém para cuidar da roça? In: Agrobiodiversidade no Brasil: experiências e caminhos da pesquisa (Ming LC, Amorozo MCM and Kffuri CW, eds.). NUPEEA, Recife, pp. 378-394.

Amorozo MCM (2013). Sistemas agrícolas de pequena escala e a manutenção da agrobiodiversidade: uma revisão e contribuições. FCA - UNESP, Botucatu.

Bandyopadhyay R, Mwangi M, Aigbe SO and Leslie JF (2006). Fusarium species from the cassava root rot complex in West Africa. Phytopathology. 96: 673-676.

Batagelj V and Mrvar A (1998). Pajek-program for large Network analysis. Connect. 21: 47-57.

Begossi A (1996). Use of ecological methods in ethnobotany: diversity indices. Econ. Bot. 50: 280-289.

Carrasco NF, Oler JRL, Marchetti FF, Carniello MA, et al. (2016). Growing cassava (Manihot esculenta) in Mato Grosso, Brazil: genetic diversity conservation in small-scale agriculture. Econ. Bot. 70: 15-28.

Castro SP (2009). Sesmaria como terra da parentalha: direito de fato versus direito legal. In: Godoi EP, Menezes MA, Marin R A (Orgs.) Diversidade do campesinato: expressões e categorias v.2 estratégias de reprodução social. Editora Unesp, Brasília, pp. 67-88. 
Cereda MP and Vilpoux O (2010). Metodologia para divulgação de tecnologia para agroindústrias rurais: exemplo do processamento de farinha de mandioca no Maranhão. Rev. Bras. Gest. Desenvolv. Reg. 6: 219-250.

Chavarriaga-Aguire PP, Maya MM, Bonierbale MW, Kresobich S, et al. (1998). Microsatellites in cassava (Manihot esculenta Crantz): discovery, inheritance and variability. Theor. Appl. Genet. 97: 493-501.

Chiwona-Karltun L, Brimer L, Saka JDK, Mhone AR, et al. (2004). Bitter taste in cassava roots correlates with cyanogenic glucoside levels. J. Sci. Food Agric. 84: 581-590.

Clement C, Cristo-Araújo D, Coppens D'Eeckenbrugge G, Alves Pereira A, et al. (2010). Origin and domestication of native Amazonian crops. Diversity. 2: 72-106.

Doyle JJ and Doyle JL (1990). Isolation of plant DNA from fresh tissue. Focus. 12: 13-15.

Duarte GSD (2015). O saber tradicional e a agrobiodiversidade na comunidade São Benedito, Poconé, MT- Brasil. Master's thesis, Faculdade de Engenharia Florestal, Universidade Federal de Mato Grosso, Cuiabá.

Duarte GSD and Pasa MC (2016). Agrobiodiversidade e a etnobotânica na comunidade São Benedito, Poconé, Mato Grosso, Brasil. Interações. 17: 247-256.

Elias M, Mühlen GS, Mckey D, Roa C, et al. (2004). Genetic diversity of traditional South American landraces of cassava (Manihot esculenta Crantz): an analysis using microsatellites. Econ. Bot. 58: 242-256.

Emperaire L and Peroni N (2007). Traditional management of agrobiodiversity in Brazil: A case study of manioc. Hum. Ecol. 35: 761-768.

Ford R (2000). Agriculture: an introdution. In: Ethnobotany: a reader. (Minnis PE, ed.). University of Oklahoma Press, Norman, pp. 243-246.

Hamlin CC and Salick J (2003). Yanesha agriculture in the upper Peruvian Amazon: persistence and change fifteen years down the 'road'. Econ. Bot. 57: 163-180.

Hammer O, Harper DAT and Ryan PD (2001). PAST: Paleontological Statistics Software Package for education and data analysis. Palaeontol. Electron. 4: 9. Available at: [http://palaeo-electronica.org/2001_1/past/issue1_01.htm].

Huberman AM and Miles M (1994). Data management and analysis methods. In: Handbook of qualitative research (Denzin NK and Lincoln YS, eds.). Sage Publications, Thousand Oaks, pp. 428-444.

Instituto Brasileiro De Geografia E Estatística, IBGE (2017). Available at [http://cidades.ibge.gov.br/xtras/perfil.php?lang=\&codmun=510650\& search=|linfogr\%E1ficos:informa\%E7\%F5es-completas/25/5/2017]. Accessed 25 May 2017.

Kombo GR, Dansi A, Loko LY, Orkwor GC, et al. (2012). Diversity of cassava (Manihot esculenta Crantz) cultivars and its management in the department of Bouenza in the Republic of Congo. Genet. Resour. Crop. Evo. 59: 17891803.

Léotard G, Duputié A, Kjellberg F, Douzery EJP, et al. (2009). Phylogeography and the origin of cassava: New insights from the northern rim of the Amazon basin. Mol. Phylogenet. Evol. 53: 329-334.

Liu K and Muse SV (2005). PowerMarker: an integrated analysis environment for genetic marker analysis. Bioinformatics. 21: 2128-2129.

Marchetti FF, Massaro LR, Amorozo MCM and Butturi-Gomes D (2013). Maintenance of manioc diversity by traditional farmers in the state of Mato Grosso, Brazil: A 20-year comparison. Econ. Bot. 67: 313-323.

Martins PS and Oliveira GCX (2009). Dinâmica evolutiva em roças de caboclos amazônicos. In: Diversidade biológica e cultura da Amazônia (Vieira ICG, Silva JMC, Oren DC and D'incao MA, eds.). Museu Paraense Emílio Goeldi, Belém, 369-384.

Mba REC, Stephenson P, Edwards K, Melzers S, et al. (2001). Simple sequence repeat (SSR) markers survey of the cassava (Manihot esculenta Crantz) genome: towards an SSR based molecular genetic map of cassava. Theor. Appl. Genet. 102: 21-31.

Montesano V, Negro D, Sarli G, Logozzo G, et al. (2012). Landraces in inland areas of the Basilicata region, Italy: monitoring and perspectives for on farm conservation. Genet. Resour. Crop Evol. 59: 701-716.

Nei M (1972). Genetic distance between populations. Am. Nat. 106: 283-292.

Olsen KM and Schaal BA (1999). Evidence on the origin of cassava: phylogeography of Manihot esculenta. Proc. Natl. Acad. Sci. U.S.A. 96: 5586-5591.

Peakall R and Smouse PE (2006). GENALEX 6: genetic analysis in Excel. Population genetic software for teaching and research. Mol. Ecol. Notes. 6: 288-295.

Peroni N and Hanazaki N (2002). Current and lost diversity of cultivated varieties, especially cassava, under swidden cultivation systems in the Brazilian Atlantic Forest. Agric. Ecosyst. Environ. 92: 171-183.

R Development Core Team (2016). R: A language and environment for statistical computing. R Foundation for Statistical Computing, Vienna, Austria. Available at: [http://www.R-project.org].

Rival L and Mckey D (2008). Domestication and diversity in manioc (Manihot esculenta Crantz ssp. esculenta, Euphorbiaceae). Curr. Anthropol. 49: 1119-1128.

Salick J, Cellinese N and Knapp S (1997). Indigenous diversity of cassava: generation, maintenance, use and loss among the Amuesha, Peruvian Upper Amazon. Econ. Bot. 51: 6-19.

Schuelke M (2000). An economic method for the fluorescent labelling of PCR fragments. Nature Biotechnol. 8: 233234. 
Siqueira MVBM, Queiroz-Silva JR, Bressan EA, Borges A, et al. (2009). Genetic characterization of cassava (Manihot esculenta) landraces in Brazil assessed with simple sequence repeats. Genet. Mol. Biol. 32: 104-110.

Siqueira MVBM, Pinheiro TT, Borges A, Valle TL, et al. (2010). Microsatellite polymorphisms in cassava landraces from the Cerrado biome, Mato Grosso do Sul, Brazil. Biochem. Genet. 48: 879-895.

Thomas M, Dawson JC, Goldringer I and Bonneuil C (2011). Seed exchanges, a key to analyze crop diversity dynamics in farmer-led on-farm conservation. Genet. Resour. Crop Evol. 58: 321-338.

Viertler RB (2002). Métodos antropológicos como ferramenta para estudos em etnobiologia e etnoecologia. In: Métodos de coleta e análise de dados em etnobiologia, etnoecologia e disciplinas correlatas (Amorozo MCM, Ming LC and Silva SP (eds.). UNESP/SBEE/CNPq, Rio Claro. 